Acta Universitatis Wratislaviensis • No 4046

Literatura i Kultura Popularna XXVI, Wrocław 2020

https://doi.org/10.19195/0867-7441.26.3

\title{
Martin Boszorád
}

ORCID: 0000-0002-8070-0554

Filozofická fakulta, Univerzita Konštantína Filozofa v Nitre, Slovenská republika

\section{Populárna kultúra v znamení Prometea (vstupné poznámky a vyhliadky)*}

Kl’účové slová: populárna kultúra/popkultúra, pragmatická estetika, arcitextuálna tematológia, prometeovský mýtus, ikonizácia utrpenia

Słowa kluczowe: kultura popularna/popkultura, estetyka pragmatyczna, tematologia literatury wysokoartystycznej, mit prometejski, ikonizacja cierpienia

Keywords: popular culture/pop culture, pragmatic/pragmatist aesthetics, arch-textual thematology, the Promethean myth, iconisation of suffering

O tom, že európska či euro-americká, resp. okcidentálna kultúra súčasnosti - a v jej rámci, pochopitel'ne, aj kultúra populárna — je do vel'kej miery fundamentálne (spolu)definovaná antikou, možno pochybovat' len sotva. Hoci sa dokonca nezdráham pomenovat' to tak, že uvedené tvrdenie má priam axiomatický charakter, to, čo sa v predloženom príspevku podujímam iniciálne, teda v zhode $\mathrm{s}$ jeho podtitulom na platforme akýchsi vstupných poznámok a vyhliadkových postrehov, reflektovat', vlastne možno vnímat' aj ako dôkaz platnosti onej úvodnej tézy.

Nedopustil by som sa dokonca ničoho neopodstatneného, keby som svoj príspevok nazval tak, že by som z neho prosto „vypustil“ prívlastok ,populárna“; trošku povrchným, beztak však funkčným argumentom legitimizujúcim takéto počínanie by mohol byt' fakt, že proprium Prometeus vlastne funguje ako, v semiotickom zmysle, znak, totiž že teda privádza na mysel' aj čosi iné ako samé

* Príspevok vznikol v rámci riešenia výskumného projektu APVV-17-0026,„Tematologická interpretácia, analýza a systemizácia arcinaratívov ako semiotických modelov životného sveta a existenciálnych stratégii'“. / The paper was written within the frame of the research grant APVV-17-0026 "Thematological interpretation, analysis and systematization of arch-narratives as semiotic models of the life world and existential strategies". 
seba. Áno, atribút „prometeovský“ (alebo jeho anglický ekvivalent Promethean) sa, pochopitel'ne, vzt'ahuje v prvom rade a predovšetkým na Prometea, v spojitosti s tým, čo ním môže byt' označované, však starogréckeho mytologického hrdinu vlastne presahuje. „Prometeovským“ napokon môže byt' akýkol’vek človek vyznačujúci sa rebelantstvom, odbojným postojom či „typ odbojného človeka vzdorujúceho tvrdému životnému údelu“l. Čosi podobné pritom platí aj v angličtine: Výraz Promethean sa referenčne viaže najprv na postavu Titana z gréckej mytológie, induktívne však môže označovat' prakticky čokol'vek, čo je „trúfalo originálne alebo kreatívne“2 . Zdá sa teda, že ak aj ešte ani nezačala byt' reč o prítomnosti prometeovskej látky v umení, určitá miera frazeologickosti ${ }^{3}$ derivátov mena Prometeus je neignorovatel'ná.

$\mathrm{V}$ istom zmysle je namieste napísat', že predmetom záujmu tohto príspevku je v synekdochickej skratke „prometeovská“ populárna kultúra/popkultúra. A hoci pri niektorých konkrétnych popkultúrnych dielach by onen prívlastok vskutku mohol fungovat' aj ako výraz toho, že sú takým či onakým spôsobom determinované vzdorom či že sú s odkazom na spomenuté slovníkové referenčné pole výrazu Promethean až trúfalo originálne alebo kreatívne, „prometeovskou“ populárnou kultúrou mienim jednoducho také popkultúrne diela, ktoré nejako pracujú s prometeovskou látkou, resp. referenčne odkazujú na prometeovský mýtus alebo ho priamo reanimujú.

Formulované inak, mojím predmetom záujmu je tu čosi, čo v rámci jednej línie svojich vedecko-výskumných aktivít za obdobie asi ostatných troch, štyroch rokov zovšeobecňujúco charakterizujem ako „väzby medzi arcitextmi a pop-textmi“. Prvý výraz v uvedenej fráze — arcitext — už bol konštituovaný ako terminus technicus, pričom označuje

príbeh či text, ktorý má z hl’adiska vývinu tej či onej kultúry (jej subsystému, areálu a pod.) osnovný, zakladajúci význam, je slohotvorný a [...] [m]ôže zároveň ustanovujúco vyjadrovat' istý životný pocit (v zmysle Heideggerovej naladenosti), poňatie životného sveta a pobytu $\mathrm{v}$ ňom (Dasein), ako aj ikonizovat' základné existenciálne stratégie, ktoré sú $\mathrm{v}$ takto poňatom svete čo najzmysluplnejšie ${ }^{4}$.

${ }^{1}$ Vo veci významu slova „prometeovský““, s ktorým tu pracujem, bližšie pozri a porovnaj internetové verzie slovenských slovníkov - Krátkeho slovnika slovenského jazyka, Slovníka cudzich slov (akademickéh) a Slovníka slovenského jazyka, https://slovnik.juls.savba.sk/?w=prometeovsk\%C3\%BD (prsítup: 15.01.2020).

2 Významové vymedzenie výrazu Promethean, s ktorým tu pracujem, bližšie pozri a porovnaj v internetovej verzii slovníka Merriam-Webster, https://www.merriam-webster.com/dictionary/Promethean (prsítup: 15.01.2020). (Citovaný úryvok, ako aj všetky ostatné citácie pôvodne v cudzích jazykoch — angličtine či nemčine — do slovenčiny preložil M.B.).

${ }^{3}$ Ked' už ako východisko svojho uvažovania spomínam vplyv antiky na súčasnú kultúru, nedá mi na tomto mieste nepripomenút', akou výraznou mierou je antikou ovplyvnená frazeológia: sizyfovský údel, Pandorina skrinka, Achillova päta, Tantalove muky, Ariadnina nit' atd’.

4 M. Čechová, Arcitextuálna tematológia, „Litikon — časopis pre výskum literatúry“ 2017, no. 1 , s. 278 . 
Druhý — pop-text — potom ako účelový, resp. vonkajškovo nápodobný pendant prvého sa sémanticky vzt'ahuje na také literárne, filmové, seriálové atd'. diela, ktoré spadajú či môžu byt' legitímne vnímané ako spadajúce do sféry populárnej kultúry. Oba pojmy pritom vlastne možno chápat' ako metodologické indície. Zatial' čo prvý z nich zastupuje arcitextuálnu tematológiu ${ }^{5}$, druhý z nich zastupuje zážitkom, recepčným účinkom a interpretáciou determinovanú estetickú reflexiu populárnej kultúry ${ }^{6}$. Metodologické prepojenie arcitextuálnej tematológie a estetickej reflexie populárnej kultúry sa mi pritom javí ako mimoriadne efektívne a produktívne inštrumentárium, a to najmä preto, že de facto neguje umelo vytvorené a, bohužial', ešte stále dostatočne „živé" axiologické oddel'ovanie údajného vysokého a údajného nízkeho (a teda akosi zákonite populárnu kultúru znehodnocujúce videnie sveta) práve tým, že - zjednodušujúco povedané - exponuje väzby medzi na jednej strane kultúrne zakladajúcim a definujúcim v kontexte minulosti (arcitexty/arcinaratívy) a kultúrne zakladajúcim či definujúcim v kontexte prítomnosti/súčasnosti (pop-texty/pop-naratívy).

K reflexii „prometeovskej“ populárnej kultúry ma na samotnom počiatku inšpirovalo predovšetkým jedno konkrétne popkultúrne dielo v znamení Prometea - film Bryana Singera Superman sa vracia (2006), inak kinematografická retro pocta superhrdinskému archetypu a jeho polymorfnej prítomnosti v západnej kultúre. Osobitne potom sekvencia, ktorej t’ažisko tvorí séria replík postavy Lexa Luthora:

Lex Luthor (prejde k svojim policiam s knihami): „Poznáš príbeh Prometea? Nie, samozrejme, že nie. Prometeus bol boh, ktorý ukradol moc nad ohňom ostatným bohom a dal kontrolu nad ním smrtel'níkom, v podstate nám dal technológiu, dal nám moc“.

Kitty Kowalski: „Takže my sa chystáme ukradnút’ oheň? V Arktíde?“

Lex Luthor: „Vlastne áno, v istom zmysle. Vieš, ktokol’vek má kontrolu nad technológiou, ten má kontrolu nad svetom. Rímska ríša vládla svetu, pretože stavala cesty. Britské impérium vládlo svetu, pretože stavalo lode. Amerika, atómová bomba. A tak d'alej a tak d'alej. Chcem len to, čo chcel Prometeus“.

Kitty Kowalski: „To znie skvelo, Lex. Ale ty nie si boh“.

Lex Luthor: „Bohovia sú sebecké bytosti, ktoré poletujú hore-dole v malých červených pláštenkách a o svoje schopnosti sa nedelia s l'udstvom. Nie, nechcem byt' bohom. Len chcem l'ud'om priniest' oheň. A chcem svoj podiel".

Citovaná sekvencia je pritom zaujímavá nielen preto, že Singerovmu režisérskemu počinu vlastne dodáva rozmer samoreferenčnosti (v rámci filmu, ktorého protagonistom je ,prometeovský“ superhrdina, predsa dochádza k explicitnej te-

5 „Arcitextuálna tematológia sa témou arcinaratívov/arcitextov zapodieva ako výrazom/prejavov (mystéria) zakladajúcej skúsenostnej a nadindividuálnej, historicky i praxeologicky overenej múdrosti, ktorá podkladá a zároveň presahuje čisto individuálne kreácie“, M. Čechová, Arcitextuálna tematológia, s. 280. K arcitextuálnej tematológii ako výskumnej špecializácii pozri bližšie (ibidem, s. 280-282).

${ }^{6} \mathrm{~K}$ tomuto prístupu k populárnej kultúre pozri bližšie najmä J. Malíček, Popkultúra: návod na použitie, Nitra 2012; idem, The Pleasure of Appearance and Knowledge - Pop Culture as Experience, Kraków 2016; R. Shusterman, Estetika pragmatizmu. Krása a umenie života, Bratislava 2003. 
matizácii prometeovského mýtu), ale aj preto, že v jej rámci sa prometeovský mýtus stáva predmetom akéhosi inverzného, možno až ideologizujúceho výkladu? Lex Luthor, teda záporná postava, hrdinova nemesis, teda reprezentant zla, sa napokon stavia do pozície Prometea, zatial' čo Supermana, teda hrdinu a reprezentanta dobra, vo svojom prehovore zase stavia do role boha, čiže kohosi, ako sa vyjadruje, sebeckého a nesolidárneho. Zároveň sa však sám usvedčuje, odhal’uje, že jeho interpretačná aplikácia prometeovského mýtu nie je plauzibilná, ked’že, ako bez škrupúl' vraví, chce svoj podiel. Nie je nezištný, nie je ochotný obetovat' svoje blaho pre blaho iných. Z toho prirodzene vyplýva, že nemôže byt' Prometeom, ergo nemôže byt' hrdinom.

Prometeus totiž bol — na rozdiel od Lexa Luthora - nezištný, bol ochotný obetovat' svoje vlastné blaho pre blaho iných, bol hrdinom. A bol (a je) aj mnohým d'alším — indivíduom mysliacim dopredu (tak sa dá preložit' jeho meno; v angličtine Forethinker, v nemčine der Vourausdenkende), bol rebelom, tricksterom, teda šibalom, zručným remeselníkom, bol tým, ktorý trpel za prečin, ale podl'a niektorých variantov jeho príbehu bol dokonca aj tvorcom človeka ${ }^{8}$. Ako som už vyššie anticipujúco naznačil, prometeovský mýtus je integrálnou súčast’ou okcidentálnej kultúrnej tradície a podstatným segmentov v rámci kultúrnej pamäti. A hoci Prometeov príbeh jestvuje $\mathrm{v}$ rôznych variáciách — predovšetkým potom v súvislosti s jeho konkrétnymi stvárneniami v konkrétnych umeleckých dielach —, je natol'ko ikonický, natol'ko kultúrne definujúci a signifikantný, že jeho ,jadro“, ktoré môžeme ponímat' ako set akýchsi kl'účových slov (oheň, krádež, trest, pečeň, orol, Kaukaz atd'.), je stále a všeobecne známe, resp. identifikovatel'né.

Zaujímavým literárnym dielom, potvrdzujúcim vlastne napriek všetkému, aj napriek „vypusteniu“ viacerých kl’účových slov, uvedené — onú identifikovatel'nost' príbehu Prometea, je Kafkova krátka próza o Prometeovi. Toto dokonca aj na Kafkove pomery bizarné, podivné podobenstvo vlastne pozostáva zo štyroch

${ }^{7}$ Rôzne, aj ideologizujúce, výklady či interpretácie prometeovského — a zrejme aj každého iného - mýtu či jeho rozdielna regionálna recepcia sa objavujú nielen v umeleckých dielach, teda vo fikcii, ale aj v našej ontologickej realite. Do istej miery uvedené potvrdzujú aj nasledujúce slová Jána Komorovského: „Sovietski básnici odmietajú Prometea ako individualistu a nadčloveka a chápu ho neodlučne od l'udského kolektívu, ktorý pokladajú za skutočného tvorcu svojich dejín a svojej civilizácie“, idem, Prometeus. Mytologické paralely, Bratislava 1986, s. 146). Autor monografie Prometeus. Mytologické paralely o kúsok d’alej pointujúco dodáva: „Tak Prometeova postava zrodená z mýtotvorby starovekých Grékov, demytologizáciou a beletrizáciou prechádzala v dejinách v symbol mnohostranného obsahu, ktorého jednotlivé aspekty sa navonok prejavili v rôznych prelomových sociálnych a politických situáciách, kultúrnych epochách i literárnych školách a myšlienkových prúdoch“, ibidem.

${ }^{8} \mathrm{~K}$ obsahu prometeovského mýtu, resp. k Prometeovmu príbehu pozri bližšie a porovnaj H.S. Daemmrich, I. Daemmrich, Themen und Motive in der Literatur. Ein Handbuch, TübingenBasel 1995, s. 281-283; E. Frenzel, Stoffe der Weltliteratur. Ein Lexikon dixhtungsgeschichtlicher Längsschnitte, Stuttgart 2005, s. 761-767; M. Lurker, Lexikon der Götter und Dämonen. Namen, Funktionen, Symbole/Attribute, Stuttgart 2014, s. 389-390; V. Zamarovský, Bohovia a hrdinovia antických bájí, Praha 1996, s. 365-368. 
úsečných juxtaponovaných legiend viazaných na antickú mytologickú postavu. A hoci Kafka zachováva či preberá ,jadro“ prometeovského mýtu, „obal“, do ktorého ho zasadzuje a to, načo sa zameriava, značne ovplyvňuje vyznenie tohto prometeovského textu. György C. Kálmán, ktorý predmetnú parabolu podrobil výkladu, v tejto súvislosti hovorí o tom, že ide zo strany autora o akt ironickej subverzie, $\mathrm{v}$ rámci ktorej sa Kafka koncentruje takmer výhradne na trest ${ }^{9}$, pričom vo svojej štúdii len o kúsok d’alej dodáva, že jednou z možných interpretácií (Kálmán ich ponúka dovedna pät') je, že Kafka vlastne paroduje snahy plne rekonštruovat' mýtus ${ }^{10}$. Ak túto hypotézu akceptujeme, akoby sa vlastne legitimizovalo narábanie — niekedy „konformné“, inokedy tvorivejšie — s prometeovskou látkou naprieč umením a populárnou kultúrou. Nehovoriac o tom, že tak de facto dochádza k akcentovaniu toho, aký komplexný a vnútorne bohato štruktúrovaný prometeovský mýtus — hoci sa to tak na prvý pohl'ad nemusí javit' — vlastne je.

Mimoriadne saturovanou a komplexnou reflexiou prometeovského mýtu je monografia nemeckého komparatistu Günthera Petersa nazvaná Prometheus. Modelle eines Mythos in der europäischen Literatur — objem materiálu, ktorý autor reflektuje, je nesmierny, rovnako ako počet autorových inšpiratívnych postrehov k problematike či otázok, ktoré v rámci nej „otvára“ (prometeovský mýtus spája v závere pomyselného dramatického oblúka aj s energetickým priemyslom, biotechnológiami či informatikou ${ }^{11}$ ). V kontexte toho, čo ma v predloženom príspevku zaujíma a akým spôsobom sa o tom snažím uvažovat', sa mi podstatné javia byt' predovšetkým nasledujúce rámcové postrehy Günthera Petersa:

Prometeovský mýtus rozpráva príbehy o antropologickej výbave človeka a ukazuje, ako je príbeh vývoja človeka zasadený do konfliktu mocností. Reflexii umelcov ponúka historicky premenlivé spektrum sebaobrazov: rolu tvorcu/stvoritel'a a rebela, spasitel'a/záchrancu a mučeníka, ale aj rolu konštruktéra alebo kaukliara a komedianta. Jeho autonómia pozostáva z múdrosti, previnenia sa, klamu, trpitel'stva, lásky k l’ud’om, nenávisti a vyrovnanosti. V súvislosti so žiadnym iným mýtom si literatúra tak intenzívne nekladie otázky týkajúce sa protirečení condition humaine [podstaty l'udskej existencie - dopl. M.B.] ${ }^{12}$.

Od začiatkov kultúrneho tradovania rozprávaní až do bezprostrednej súčasnosti siaha ,práca na mýte‘ Prometea. Hesiodos, Aischylos, Platón, Aristofanés a Lukianos voviedli Prometea ako klúčovú figúru do mytologického, literárneho a filozofického diskurzu. V súperení Titana s bohom Diom sa sformovali základné štruktúry l'udského bytia. Spojenie s postavami ako Epimeteus, Pandora alebo Herakles/Herkules stupňovalo dosah mýtu a spustilo do behu až dodnes živé obrazové myslenie v polaritách a konšteláciách ${ }^{13}$.

Uvedené fragmenty Petersovho uvažovania o modeloch prometeovského mýtu v kontexte európskej slovesnosti som si dovolil odcitovat' v ich plnom znení preto,

9 G.C. Kálmán, Kafka’s Prometheus, „Neohelicon“ 2007, no. 1 (34), s. 52.

10 Ibidem, s. 53.

11 Bližšie pozri v záverečnej kapitole Petersovej monografie nazvanej Von der Flamme zu den Genen, Rückkehr des Prometheus in den Alltag der Moderne; idem, Prometheus. Modelle eines Mythos in der europäischen Literatur, Weilerswist 2016, s. 505-535.

12 G. Peters, Prometheus. Modelle eines Mythos in der europäischen Literatur, s. 32.

13 Ibidem (z obalu - nečíslované). 
že sú, nazdávam sa, funkčným východiskom v súvislosti s tézou, ktorej odôvodnenost' sa budem d'alej snažit' v skratke preukázat', teda s tézou, že miera Prometeovej prítomnosti v umení a populárnej kultúre je zretel'ahodná, a to nielen ako postavy stelesňujúcej ikonický obraz utrpenia, resp. trestu za prekročenie hranice.

V princípe sa — aspoň tak sa mi to $\mathrm{v}$ okamihu písania predloženej state javí — dajú rozlíšit' dve vnútorne d’alej členené polohy prítomnosti, resp. ozvuku prometeovského mýtu v umení a populárnej kultúre.

V prvej polohe je väzba toho-ktorého diela na prometeovský mýtus explicitná a konkrétna na jednej strane, alebo implicitná a abstraktnejšia na strane druhej. Ako ilustratívne príklady možno v tejto súvislosti vedla seba postavit' napríklad mal'bu Petra Paula Rubensa Spútaný Prometeus a ikonické súsošie Láokoón a jeho synovia. Obe výtvarné diela zobrazujú postavu/postavy v okamihu utrpenia a obe možno interpretovat' práve prostredníctvom ,jadra“ prometeovského mýtu, ktorým je, ako to v podstate pripomína aj Komorovský ${ }^{14}$, prečin (akcia) a trest zaň (reakcia). Zatial' čo Prometeus sa krádežou ohňa vzoprel bohom, za čo bol potrestaný, Láokóon sa upozorňovaním na lest' v spojitosti s Trójskym koňom vzoprel bohom a Osudu:

Iba Láokoón nestratil potrebnú mieru ostražitosti. Prehlásil, že nepriatel'om neverí ani ked' prinášajú dary a navrhol, aby koňa namieste zničili. Osud však určil, že Trója má padnút: bohovia museli teda Láokóna umlčat'. Ked’ Láokoón nezískal pre svoj návrh podporu, vzal kopiju a pokúsil sa rozbit' koňa sám. V tej chvíli však vyliezli z pokojného mora dva hady ${ }^{15}$.

V druhej polohe je potom takisto dôležitá väzba toho-ktorého diela na prometeovský mýtus, avšak inak, v inom zmysle. Podstatné totiž je to, či je referencia tvorená prostredníctvom prvku či „momentu“ prometeovského mýtu ako toposu (opät' tu vlastne máme dočinenia s čímsi, čo je konkrétne „prometeovské“), alebo či je — na abstraktnejšej, abstrahovanej úrovni — ,jadro“ prometeovského mýtu v tom-ktorom diele prítomné ako syntax, resp. syntaktická štruktúra či vzorec. Napríklad film Prometheus Ridleyho Scotta prostredníctvom názvu ústrednej prieskumnej vesmírnej lode sa ako filmový prequel referenčne viaže na prometeovský mýtus rozširujúcim dorozprávavaním „votreleckej“ mytológie (cez postavy mysterióznej rasy inžinierov, cez motív prekročenia hranice po poznaní bažiacej posádky). Lenže ozvuk prometeovského mýtu môže byt' $\mathrm{v}$ umení a populárnej kultúre využitý aj abstraktnejšie, a síce tak, že diela sú na tematickej úrovni jednoducho vystavané na jeho abstraktnom, generálnom naratívnom pôdoryse „,prečin — trest — vykúpenie/oslobodenie“. V tomto prípade potom takto vymedzený naratívny pôdorys prometeovského mýtu, prítomný fakticky v obrovskom množstve príbehov naprieč druhmi a žánrami, napíňa podstatu toho, čo sa $\mathrm{v}$ rámci

14 „Grécky mýtus o Prometeovi spočíva na dvoch základných momentoch: a) krádež ohňa, ktorý sa má stat' l’ud’om začiatkom kultúrneho života a civilizácie; b) konflikt s Diom“, J. Komorovský, Prometeus. Mytologické paralely, s. 18-19.

15 V. Zamarovský, Bohovia a hrdinovia antických bájí, s. 245. Ad hoc a čisto kvôli plynulosti a jazykovej homogenite textu z češtiny do slovenčiny preložil M.B. 
arcitextuálnej tematológie nazýva osnovným tematickým algoritmom, teda akejsi univerzálne(jšie) uplatnitel'nej a aj uplatňovanej príbehovej osnovy ${ }^{16}$.

Blížiac sa pomaly $\mathrm{k}$ záveru svojho vo vzt’ahu $\mathrm{k}$ problematike reanimácie prometeovského mýtu ako vstup koncipovaného príspevku, sa chcem ešte vrátit' k explicitnejšie „V znamení Prometea“ sa nesúcim popkultúrnym dielam a referenčne spomenút' niekol'ko z nich, ktoré sú $\mathrm{v}$ tomto kontexte $\mathrm{z}$ môjho pohl'adu osobitne hodné pozornosti.

V roku 1997 sa v piatej sezóne Aktov X objavila epizóda s názvom The Post-Modern Prometheus. Tento diel sa, pochopitel'ne, viaže na staroveký mýtus o Prometeovi, predovšetkým sa však viaže na ikonicky prometheovský román Mary Shelleyovej Frankenstein or The Modern Prometheus (1818) a jeho filmovú adaptáciu z roku 1931 v réžii Jamesa Whalea, ktorej sa, takpovediac, prispôsobuje aj štýlovo, atmosféricky, esteticky (čierno-biely obraz, práca so svetlom a tieňom, spôsob snímania atd’.). A robí tak v zhode so svojím názvom vyslovene v duchu postmoderny, a to predovšetkým vd'aka svojej referenčnej, resp. silne intertextuálnej zosiet'ovanosti. Obdobne sa takáto prometheovská epizóda s výrazným „meta“-rozmerom objavila v rámci seriálu Hrozba z temnoty, ktorý má ako celok výrazný „meta“-charakter, a to v roku 2013 a pod mnohovravným názvom $R e$ member the Titans. Tvorcovia $\mathrm{v}$ tomto prípade príliš neexperimentujú $\mathrm{s}$ formou (ako v epizóde Aktov $X$ ), tvorivo však pracujú s reanimáciou prometeovskej látky na úrovni obsahu. Kl'účovým je v tomto kontexte najmä to, že ústrednou postavou narácie sa stáva samotný „,nezabudnutý“ Titan Prometeus, ktorý však — paradoxne - trpí amnéziou a jediné, čo vie, je, že opakovane, v nekonečnej slučke umiera. Iným dôležitým — a nie seriálovým — popkultúrnym dielom nesúcim sa „v znamení Promethea“ je videoherný titul God of War 2, v rámci ktorého hráč $\mathrm{v}$ úlohe protagonistu hry Krata $\mathrm{v}$ istej fázy hry natrafí na pripútaného a trpiaceho Promethea, aby ho napokon oslobodil spod jarma večných múk a doprial mu tak vyslobodenie (v podobe smrti).

Podstatné - a predovšetkým v súvislosti s preukázaním faktickej sily ohlasu prometeovského mýtu v populárnej kultúre — pritom je, že v prípade všetkých uvedených popkultúrnych diel je vlastne reč o významných, dôležitých a v istom zmysle nosných dielach. Shelleyovej román napokon stál pri zrode ,jadra“ populárnej kultúry, teda fantastiky a žánrovej fikcie (horor, sci-fi), God of War patrí k najikonickejším a najoceňovanejším videoherným franšízam vôbec a seriály Akty $X$ a Hrozba z temnoty majú široké fanúšikovské základne, o čom okrem iného svedčí aj to, ako často sa stávajú predmetom fan fiction.

Už len z tematizovaných príkladov — a to som vlastne spomínal len tie explicitne „prometeovskéc“ — je, zdá sa mi, zrejmé, že populárna kultúra je promete-

16 K vymedzeniu osnovného tematického algoritmu pozri bližšie Čechová a kol., Osnovné tematické algoritmy $v$ slovesnom umení (intersemiotickými a interdisciplinárnymi presahmi), Nitra 2016, s. 7-8; M. Čechová, Tematický algoritmus. „Litikon — časopis pre výskum literatúry“ 2017, no. 1, s. 279 . 
ovským mýtom poznačená (v dobrom slova zmysle) vel’mi výrazne. Náhodou som pred časom na internete natrafil na komiksový strip istého Scotta Maynarda s názvom Playing with Fire. Strip vtipným spôsobom reanimuje, resp. reinterpretuje ten najpodstatnejší segment prometeovského mýtu, ked' v troch políčkach zobrazuje Prometeovo obdarovanie l'udstva ohňom. Vtipná pointa sa pritom objavuje v tret’om políčku, ktoré zobrazuje l’udí využívajúcich dar ohňa svojským spôsobom - tieňovým divadlom pomocou rúk. Maynardov strip by sa dal interpretovat' prostredníctvom ikonického Platónovho Podobenstva o jaskyni, omnoho zaujímavejšie sa mi však takto na záver zdá interpretovat' ho prostredníctvom odkazu na akiste najesenciálnejš́ fundament populárnej kultúry. V Maynardovom komiksovom stripe sa totiž vlastne l'udia vd'aka Prometeovi vel'mi dobre bavia zakúšajú nevšedný estetický zážitok, vyplńajú svoj čas obohacujúcim spôsobom, kultivujú sa atd'. A toto je, myslím, nateraz zmysluplná pointa: To, čo sa vd’aka Prometeovi deje v Maynardovom stripe, sa vlastne deje (aj vd'aka Prometeovi) tiež mimo neho — v populárnej kultúre ako takej.

\section{Bibliografia}

\section{Pramene}

\section{Filmografia}

Akty X (The X-Files), USA-Kanada 1993-2018.

Frankenstein, smer J. Whale, USA 1931.

Hrozba z temnoty (Supernatural), USA 2005-2020.

Prometheus, smer R. Scott, USA-Vel'ká Británia 2012.

Superman sa vracia (Superman Returns, dir. Bryan Singer, USA/Austrália 2006)

\section{Hry}

God of War 2, prod. Santa Monica Studios, USA 2007.

\section{Literárne diela}

Kafka F., Prometheus, https://biblioklept.org/2012/10/13/prometheus-kafka/.

Maynard S., Playing with Fire, http://www.happletea.com/comic/playing-with-fire/.

Shelleyová M.W., Frankenstein, čiže moderný Prometeus, Tatran, Bratislava 1991.

\section{Sekundárne zdroje}

Armstrong K., Dejiny mýtov, Slovart, Bratislava 2005.

Čechová M., Arcinaratív/arcitext, ,Litikon — časopis pre výskum literatúry“ 2017, no. 1, s. 278 279. 
Čechová M., Arcitextuálna tematológia, „Litikon — časopis pre výskum literatúry“ 2017, no. 1, s. $280-282$.

Čechová M., Tematický algoritmus, „Litikon — časopis pre výskum literatúry“ 2017, no. 1, s. 279.

Čechová M. et al., Osnovné tematické algoritmy v slovesnom umení (intersemiotickými a interdisciplinárnymi presahmi), Univerzita Konštantína Filozofa, Nitra 2016.

Daemmrich H.S., Daemmrich I., Themen und Motive in der Literatur. Ein Handbuch, Francke Verlag, Tübingen-Basel 1995.

Frenzel E., Stoffe der Weltliteratur. Ein Lexikon dixhtungsgeschichtlicher Längsschnitte, Alfred Kröner Verlag, Stuttgart 2005.

Hecken T., Theorien der Populärkultur: Dreißig Positionen von Schiller bis zu den Cultural Studies, transcript Verlag, Bielefeld 2007.

Kálmán G.C., Kafka’s Prometheus, „Neohelicon“ 2007, no. 1 (34), s. 51-57.

Komorovský J., Prometeus. Mytologické paralely, Smena, Bratislava 1986.

Kovalčik J., Ryynänen M., A History of Aesthetics of Popular Culture, [w:] Aesthetics of Popular Culture, red. J. Kovalčik, M. Ryynänen, Academy of Fine Arts and Design \& Slovart Publishing Ltd., Bratislava 2014, s. 14-49.

Lurker M., Lexikon der Götter und Dämonen. Namen, Funktionen, Symbole/Attribute, Alfred Kröner Verlag, Stuttgart 2014.

Malíček J., The Pleasure of Appearance and Knowledge - Pop Culture as Experience, Spolok Slovákov v Pol’sku/Towarzystwo Słowaków w Polsce, Kraków 2016.

Malíček J., Popkultúra: návod na použitie, Univerzita Konštantína Filozofa, Filozofická fakulta, Nitra 2012.

Peters G., Prometheus. Modelle eines Mythos in der europäischen Literatur, Velbrück Wissenschaft, Weilerswist 2016.

Peters G., Von der Flamme zu den Genen, Rückkehr des Prometheus in den Alltag der Moderne.

Shusterman R., Estetika pragmatizmu. Krása a umenie života, Kalligram, Bratislava 2003.

Zamarovský V., Bohovia a hrdinovia antických bájí, Brána \& Knižní klub, Praha 1996.

\title{
Popular culture in the sign of Prometheus (initial notes and prospects)
}

\author{
Summary
}

Methodologically connecting the experience and interpretation-based aesthetic approach to popular culture (Juraj Malíček) and pragmatist aesthetics (Richard Shusterman) on one hand and the views of what is called arch-textual thematology (Mariana Čechová) on the other, the paper seeks to observe the ties between an arch-text, in this particular case the Promethean myth, and "pop.-texts", i.e. such pop cultural works of art (films, TV series, literary texts, comics etc.), within the framework of which the Promethean myth appears in one way or another and which can be labelled with the agnomen "pop". The consideration is core-like based on the exceedingly saturated and complex work of the German comparatist Günter Peters entitled Prometheus: Modelle eines Mythos in der europäischen Literatur (2016) in which the author thematises models of the Promethean myth in the context of European verbal art. Various models or appearances of a reanimation of the Promethean myth in various (pop cultural) works of art become in the paper referentially an object of interest - from Kafka's parable about Prometheus through "Promethean" episodes of TV series like The X-Files (1997), Bones (2013), a Supernatural (2013) and films like Prometheus (2012) to the Promethean and iconic novel by Mary Shelley Frankenstein (1818) and its adaptations. The basic leitmotif of the paper is in a sense the problem of the iconisation of suffering as a principal thematic segment of the Promethean myth.

Literatura i Kultura Popularna 26, 2020

(C) for this edition by CNS 